The research program of the Center for Economic Studies (CES) produces a wide range of theoretical and empirical economic analyses that serve to improve the statistical programs of the U.S. Bureau of the Census. Many of these analyses take the form of CES research papers. The papers are intended to make the results of CES research available to economists and other interested parties in order to encourage discussion and obtain suggestions for revision before publication. The papers are unofficial and have not undergone the review accorded official Census Bureau publications. The opinions and conclusions expressed in the papers are those of the authors and do not necessarily represent those of the U.S. Bureau of the Census. Republication in whole or part must be cleared with the authors.

\title{
EXPLORING THE ROLE OF ACQUISITION IN THE PERFORMANCE OF FIRMS: IS THE "FIRM" THE RIGHT UNIT OF ANALYSIS?
}

\author{
By \\ Robert $\mathrm{H}$. McGuckin and Sang V. Nguyen* \\ Center for Economic Studies \\ U.S. Census Bureau \\ Email: mcguckin@census.gov / snguyen@census.gov \\ (301) 457-1848
}

CES 95-13 November 1995

All papers are screened to ensure that they do not disclose confidential information. Persons who wish to obtain a copy of the paper, submit comments about the paper, or obtain general 
information about the series should contact Sang V. Nguyen, Editor, Discussion Papers, Economic Planning and Coordination, Census, Washington, DC 20233-6101, (301)-457-1882) or INTERNET address snguyendinfo.census.gov.

\section{Abstract}

In this article, we examine the effect of acquisitions on productivity performance of acquiring firms using the conventional regression analysis and a method of productivity decomposition. Our empirical work uses both plant- and firmlevel data taken from the Longitudinal Research Database (LRD) on the entire population of U.S. food manufacturing firms that operated continuously during 1977-87. We find that (1) acquisitions had a significant, positive effect on acquiring firms' productivity growth, but this effect becomes insignificant when only firm-level data on multi-unit firms are included in the regressions; and (2) the decomposition results show that while the productivity contribution of the external component (acquired plants) is positive, the contribution of the internal component (existing plants) is negative; the two components offset each other leaving productivity of multi-unit acquiring firms virtually unchanged after acquisitions. These results suggest that assessing the impact of acquisitions on the structure and performance of firms requires a careful look at the individual components (i.e., plants) of the firms, particularly for large multi-unit firms.

Keywords: acquisitions, acquiring firms, relative labor productivity 
* Center for Economic Studies, U.S. Bureau of the Census. The judgements and conclusions herein are those of the authors and do not necessarily reflect those of the U.S. Bureau of the Census. Thanks are gratefully given to participants in seminars at the Center for Economic Studies, Chicago Federal Reserve, and the Productivity Program at NBER's Summer Institute, July, 1995. There is an enormous volume of empirical studies on mergers and acquisitions, both from the finance and industrial organization perspectives. ${ }^{1}$ The large scale interest in these transactions is not surprising. Mergers and acquisitions involve the ownership transfer of enormous quantities of assets and affect hundreds of thousands of workers and shareholders each year. Moreover, while in principle, "internal" growth -- changes in existing capacity or creation of new capacity -- and "external" growth -- increase in capacity through acquisitions -are analogous mechanisms to alter the structure and scale of a firm's productive capabilities, external growth has long been associated with controversy.

Much of the early concern arose from the possibilities for increases in market power associated with acquisitions (e.g., Stigler, 1950). Recent interest has centered on whether acquisitions are undertaken primarily by opportunistic managers (insulated from shareholders) to pursue their own objectives, or to discipline poorly performing managers. ${ }^{2}$ The former focus has been fueled by a lack of empirical evidence of gains to acquiring firms' shareholders in event studies. The typical industrial

\footnotetext{
Mueller (1993), for example, lists 123 studies in his bibliography, and there are many more.

2 The idea that the objectives of stockholders and managers might diverge originated in the classic study by Berle and Means (1932). This theme has been explored by many, including Manne (1965), Grossman and Hart (1979), and Jensen (1988). Baumol (1967) and Mueller (1969) and (1993) argue that managers might engage in acquisitions for empire-building motives. Managers might also try to entrench themselves (Shleifer and Vishny, 1989), or managers might systematically overestimate their ability to improve the acquired firms' performance (Roll, 1986).
} 
organization study has also found little in the way of gains to mergers and, since acquired firms are generally profitable prior to merger, it has been argued that profits are available for opportunistic managers to expropriate. ${ }^{3}$

Although, there are explanations for why mergers and acquisitions do not improve the performance of the acquiring firm or serve its stockholders, the absence of almost any observed gains to acquiring firms is still a puzzle in light of the large and continuing volume of acquisition activity observed in the economy. Even if shareholder and managerial interests diverge, one would not expect a continuing pattern of bad deals for acquiring firms. ${ }^{4}$ Most studies of mergers and acquisitions use firm level data and it is possible that this level of analysis is simply to aggregative to identify acquiring firm gains.

If an acquisition is part of a strategy to realign the resources and operations of the firm -- a strategy that may encompass acquisition, divestiture, and internal growth -- the composition effects can be important in assessing the gains or losses to the transaction. Thus, simply looking at performance (e.g., profits or productivity) of a firm before and after a

\footnotetext{
While there are exceptions, the typical finance study concludes that the overall gains from merger are positive. But with few exceptions they also find most, if not all, of the gains accrue to the selling firms' shareholders and not to those of the acquiring firm. On average, shareholders of acquiring firms in mergers and tender offers gained 20 and 32 percent, respectively. However, the gains for acquiring firms' shareholders were either small or not statistically significantly different from zero (Jensen and Ruback, 1983, Smith, 1986, and Jarrell et al., 1988). Recently, Kaplan (1989) studies 48 management buyouts and finds an increase in operating returns after buyouts. Smith (1990) uses a similar dataset with different methodologies and finds similar results. Matsusaka (1993) and Klein(1995) find that a subset of acquisitions achieved significant returns. But, they also find that on average, returns to acquirers are near zero. Industrial organization studies (e.g., Ravenscraft and Scherer 1987), by and large, also find little in the way of gains to acquirers. Moreover, industrial organization studies of mergers in the 1950s, 1960s, and early 1970s generally found negative effects on efficiency from mergers (see Mueller, 1993).

4 The "bidder's curse" which may be relevant to hostile takeovers would not seem relevant to most mergers which involve friendly transactions.
} 
merger may not adequately control for the conditions that the firm faces or expects to face. This point is certainly true for industrial organization studies, but it also affects finance studies, particularly for small changes in the structure of the firm or situations where a firm undergoes a series of transactions. Moreover, developing an appropriate portfolio to control for systematic market effects in finance studies is not a trivial matter. ${ }^{5}$

Recent empirical work with sub-firm level data on plants supports the hypothesis that the lack of observed gains to mergers and acquisitions could be associated with use of firm level observations that obscure the effects of acquisitions, particularly in large multi-unit firms. Lichtenberg and Siegel (1992), Long and Ravenscraft (1993), McGuckin and Nguyen (1995) and McGuckin, Nguyen, and Reznek (1995) all provide strong evidence that plants undergoing ownership change show increases in productivity. Baldwin and Gorecki (1991) also find improved performance following plant ownership changes using Canadian data. None of these studies deals explicitly with acquiring firms. ${ }^{6}$ Rather, they examine the performance of plants before and after they were transferred from one firm to another. These plant-level studies suggest that the failure of most firm-level studies to find any significant, positive effect of acquisitions on acquiring firms' performance may stem from aggregation biases that are associated with the use of samples dominated by large multi-unit firms.

In this study, we use both plant and firm-level data for the food manufacturing industry (SIC 20) over the period 1977-87

\footnotetext{
See Klein (1994), and McGuckin, Warren-Boulton, and Waldstein (1992) for examples of the problem.

The work on LBOs by Long and Ravenscraft (1993) and Lichtenberg (1992) deals consists mostly of smaller single plant firms. In single plant firms the plant and firm are identical units of analysis.
} 
taken from the Longitudinal Research Database (LRD) to compare the differences, if any, that result from using different units of analysis to examine the effects of acquisitions on the performance of acquiring firms. The LRD data overcome a major difficulty in the empirical literature on mergers and acquisitions: The lack of data to directly estimate the contributions of the components of a firm to its performance. As stated by Mueller (1993), "Any real [emphasis in original] consequences of a merger must come about through changes in the development of one or both joining units that can be attributed to the merger in the following year." This requires plant-level data that provide information on the components of acquiring firms before and after acquisitions.

Using the LRD data, we estimate the effect of acquisitions on acquiring firms' productivity growth -- which we use as a measure of performance -- at the firm level. We then apply the same analysis, but using plant-level data to test for possible aggregation biases introduced by the use of aggregated firm level data. Several findings emerge from this analysis. First, our regression results based on the entire data set, including both single and multi-unit firms, show that acquisitions have a significantly positive effect on acquiring firms' productivity growth. More specifically, during the 10-year period 1977-87 the typical surviving acquiring firm enjoyed a labor productivity growth rate of 48.8 percent higher than that of its non-acquiring firm counterpart (i.e., 4.88 percent per year). However, when applying the model to multi-unit firms only, we find an insignificant effect of acquisitions on acquiring firms' productivity growth.

Second, estimates of the model based on plant-level data uniformly show that acquired plants' labor productivity growth is significant higher than that of non-acquired plants 5 to 10 years after acquisitions. Thus, using the disaggregated plant-level 
data reveals improvement in acquired plant productivity in both single and multi-unit firms. Although the improvement is larger in single unit firms, both groups show significant gains. Moreover, and this was somewhat of a surprise in light of the firm level results, the plants of multi-unit firms which were owned prior to acquisition also showed improved performance, although somewhat less, in the period after the acquisition.

In order to explore this issue further, we turn to a decomposition of productivity change for multi-unit firms during the 1977-87 period into three components: internal (plant's continuously operating), external (plant's acquired and sold), and internal restructuring (plants closed and built). The results of this decomposition confirm that the external component (acquired plants) is large and has a positive influence on productivity change. In contrast, the contribution of the internal component (continuous existing plants) in productivity change of acquiring firms is negative. The source of this negative effect is almost entirely associated with a decline in the share of the firm attributable to continuously operating plants. While there is a trivial decline in the productivity of previously owned plants relative to the average plant in the industry, these plants are more productive than acquired plants both before and after acquisition. Thus, in the restructuring of multi-unit acquiring firms the external and internal components offset each other, leaving these firms' labor productivity virtually unchanged at the same above average levels observed before the acquisitions. These results strongly suggest that acquisitions have a significantly positive effect on acquiring firms which cannot be captured by a firm-level regression analysis that is based upon a sample of large multi-unit firms. The paper is organized into 4 sections. Section I describes our data source, sample design, description of the data, and performance measurement. Section II presents our regression 
analysis at both the firm and plant levels. Section III discusses our procedure of decomposing firms' productivity growth and reports the results. Section IV discusses our principal findings and concludes the paper.

\section{EMPIRICAL STRATEGY AND PERFORMANCE MEASUREMENT \\ A. Data and Sample Design}

\section{Data Source}

The LRD, maintained at the U.S. Bureau of the Census' Center for Economic Studies (CES), provides the data for this study. The LRD contains a variety of information on individual U.S. manufacturing establishments, mostly reported annually. By and large, the data relate to the production of establishments, including output measures such as value of shipments and labor input for the complete population of manufacturing plants at five year intervals. The LRD also contains information on classification and identification, such as plants' ownership, location, product and industry, and various status codes that identify, among other things, birth, death, and ownership changes. These identifying codes are used in developing both the longitudinal plant linkages and ownership linkages among plants. ${ }^{7}$

\section{Sample Design}

In this study, we use data for the food manufacturing industry (SIC 20) over the period 1977-87 to examine acquisition activity. This industry exhibited substantial ownership change activity during the period and provides a large, but tractable, set of firms for this data intensive project. The sample includes all food manufacturing firms that survived over the ten

(1988) .

For a detailed description of the LRD, see McGuckin and Pascoe 
year period or entered through a diversification acquisition and retained some portion of the properties they purchased. ${ }^{8}$

For each food manufacturing firm, all of the manufacturing plants under its ownership in 1977 and 1987 are identified. This enables us to calculate the productivity of the firm in each year as a weighted average of the productivity of the firms' individual plants in that year. We are also able to make similar calculations for various groups of individual plants that make up the components of the firm (e.g., kept plants, acquired plants, new plants, divested plants, etc.).

We also obtain similar data for firms that operated in the food manufacturing industry and did not participate in any acquisition activity. This provides a control group for the analysis of the relative performance of firms growing through external and internal means. While we do not attempt to include greenfield entrants and firms operating in 1977 that closed during the period directly, they are included in the aggregate industry productivity figures we use to "deflate" the individual plant productivity measures (see below). ${ }^{9}$

\section{B. Performance Measurement}

The best-known measure of efficiency performance is productivity, measured as the ratio of firm output to its inputs.

\footnotetext{
The sample was developed by first identifying each food plant undergoing an ownership change during 1977-82 and the subsequent period 198287. These five year intervals coincide with manufacturing censuses and thereby ensure that all ownership changes are identified. By separately identifying ownership changes in the 1977-82 period, we are able to examine the evolution and performance of acquiring firms and their components 5 to 10 years after the acquisitions took place. This provides sufficient time to ensure the acquired assets have been "digested". Note that some of the firms we label as non-acquirers had acquisitions in the 1983-87 period. How we treat this group affects the magnitude of the numbers we report, not the conclusions we draw.

9 In the short time period examined, greenfield entry accounts for a very small proportion of this output.
} 
We use value of shipments rather than value-added as our output measure because data on value-added are not always available, particularly for small plants. In practice, productivity results using either measure are highly correlated. For example, the results in McGuckin and Nguyen (1995), which also used food industry data over this period, were unaffected by the choice of value added or value of shipments. (See also Baily, Campbell, and Hulten, 1992; and Baily, Bartelsman, and Haltiwanger, 1994).

Productivity can be either measured for each single input such as labor (the well-known labor productivity) or measured for all inputs, total factor productivity (TFP). Theoretically, TFP is the appropriate measure of productivity because it takes into account all inputs. In practice, labor productivity is often used because data on inputs, such as capital, that are required for the measurement of TFP are not available. Because of data limitations, we base our analysis on labor productivity.

Plant labor productivity, LP, is measured as value of shipments in current dollars divided by the total number of employees. While output prices and value of shipments vary across plants and over time because of price dispersion and inflation, deflating each plant's labor productivity by its industry average labor productivity produces a comparable productivity measure through time. ${ }^{10}$ We term this adjusted labor productivity measure as relative labor productivity, RLP.

Plant RLP provides a good measure of plant performance if all plants in the same industry have similar input-output ratios. However, if the production technology differs substantially among plants, labor productivity could be a misleading measure of performance. In our earlier work (McGuckin and Nguyen, 1995), we estimated TFP for a number of large plants for which the required

10 Industry is defined at the 4-digit level throughout the paper. 
data were available. We then compared the TFP results to the RLP results, and found that both measures led to the same conclusions regarding plant performance.

While single-unit firms are classified in a single industry, multi-unit firms often have plants operating in various industries. ${ }^{11}$ For multi-unit firms, we calculate the productivity for each plant separately, then obtain the firm productivity as a weighted sum of plant productivities. Thus, we measure the relative labor productivity of the firm by

$$
L P_{k}^{F}=\sum_{j}^{n} w_{k j} L P_{k j^{\prime}}
$$

where $\mathrm{LP}_{\mathrm{k}}^{\mathrm{F}}$ is LP of firm $\mathrm{k}$, the weight $\mathrm{w}_{\mathrm{kj}}$ is the ratio of plant j's employment to the total number of employees of firm $k$. The use of labor weights provides for an exact aggregation of the plant data to the firm level. This relative ranking approach was suggested by Christensen, Cummings, and Jorgenson (1981) and has been applied in recent productivity analyses using plant-level data from the LRD (e.g., see Olley and Pakes, 1992; Bartelsman and Dhrymes, 1992; Baily, Campbell, and Hulten, 1992; and McGuckin and Nguyen, 1995). The RLP measure does not depend on an output deflator because, in any given year, output in all plants is measured in the same unit (i.e., dollars). Accordingly, it can be used in intertemporal comparisons.

\section{Description of the Sample}

\section{Sample Coverage}

As shown in Table I for the period 1977-82, we identified 732 acquiring firms that purchased at least one food manufacturing plant. These firms acquired 2,113 plants -- 1,575 food and 538 non-food plants -- from 733 firms selling at least

\footnotetext{
11 Abbott (1989) used plant-level data extracted from the 1982 Census of manufactures to analyze output prices across producers. He found that prices vary substantially across plants, even at the 7-digit product level.
} 
one plant over the period (another 2,382 plants were acquired in the 1983-87 period). The acquisitions accounted for a large fraction of the food industry: acquired value of shipments amounted to 38,764 million dollars or 21 percent of the 1977 value of shipments of the entire food manufacturing industry (SIC 20).

\section{Characteristics of Acquired Firms}

In Table I, the 732 acquiring firms consist of 93 singleunit firms, 284 multi-unit non-manufacturing ${ }^{12}$ firms, and 355 multi-unit manufacturing firms. Of the 284 multi-unit firms with non-manufacturing activities, 134 entered manufacturing by acquiring one manufacturing plant. Each of the remaining 150 non-manufacturing firms acquired at least two manufacturing plants (431 in total).

For the non-acquiring group, we identified 17,409 firms that had at least one food manufacturing plant in 1977. Of the 17,409 firms, 15,067 were single-unit firms, 1,185 non-manufacturing firms had one food manufacturing plant, and 1,157 were multi-unit manufacturing firms. Some of the latter category of firms had non-manufacturing operations, but we can't separately identify them with the LRD.

Multi-unit manufacturing firms accounted for most of the acquisition activity. These firms acquired 1,455 of 2,113 transferred plants (69 percent), that accounted for 35,571 million dollars in 1977 value of shipments acquired or 92 percent of total acquired shipments. Multi-unit manufacturing firms also were most important among the non-acquirers. The 1,157 nonacquiring multi-unit firms owned 7,701 manufacturing plants (both food and non-food plants) in 1977 shipments. These accounted for

12 We identified these firms as non-manufacturing because they had a multi-unit identification, but did not have any manufacturing plants before acquisition. 
129,446 million dollars in value of or 79 percent of nonacquirer's total shipments in 1977.

The average size of acquiring firms in all categories is much larger than that of non-acquiring firms. The average sizes of acquiring single-unit firms, multi-unit non-manufacturing firms, and multi-unit manufacturing firms are 158, 131 and 3,389 employees, while those of non-acquiring firms are 19, 70 and 1,083, respectively.

Table I shows that measured levels of productivity are generally lower for single than multi-unit firms. ${ }^{13}$ In addition, the productivity of acquiring firms is uniformly higher than that of non-acquiring firms. For example, the average labor productivity of multi-unit acquiring firms is 1.11 (i.e., 11 percent above industry average), while that of non-acquiring multi-unit manufacturing firms is only.97, slightly below industry average.

In summary, the data show that, in contrast to non-acquiring firms, acquiring firms are bigger and more productive. In addition, while not reported, the data also suggest that survival rates are higher for acquiring firms and that they are more likely to be involved in business transfers in the subsequent period than non-acquiring firms. ${ }^{14}$

13 We think part of this is real and part of it derives from unmeasured central office and related auxiliary operations that are more prevalent among multi-unit firms. Productivity for small single-unit firms, both acquiring and non-acquiring, is below that of the larger multi-unit firms because of measurement errors associated with services from central offices, as well as the positive relationship between size and productivity.

14 Probit regressions (not reported here) show significant, positive relationships between both size and initial productivity, and the probability of being an acquiring firm. Moreover, the relationships are non-linear. 


\section{THE EFFECTS OF UNIT OF ANALYSIS ON ESTIMATES OF THE IMPACTS OF ACQUISITIONS ON ACQUIRING FIRMS}

In this section we undertake a two step examination of the impact of acquisitions on the RLP of the firm. First we run regressions of productivity performance for our entire sample at the firm level. Then we perform the same analysis separately for single-unit and multi-unit firms and compare the results. Single-unit firms are essentially the same as plants and the results for this group of firms should be similar to those found in the plant-level studies cited earlier. If there are significant composition effects they should be observed in the multi-unit portion of the sample.

To test for aggregation biases, we perform a similar regression analysis based on plant-level data. The plant-level specifications allow us to examine the performance of both acquired and previously owned plants for multi-unit firms. This provides a direct comparison to the firm level results and some indication of the source of any differences.

Our model specifications follow McGuckin and Nguyen (1995): We regress growth rates of RLP on the firm's initial (1977) RLP, size (log $\left.\mathrm{TE}_{77}\right)$, and a dummy variable identifying whether a firm is an acquiring firm. We also include other dummy variables to capture the effects of industry and the types of firm (i.e., single versus multi-unit firms) and allow for interactions between some key variables.

\section{A. Firm-Level Results}

Table II reports the firm-level regression results. In the equations, the variable $\mathrm{ACQFIRM}$ equals 1 if the firm is an acquiring firm during 1977-82; otherwise it equals $0 . \mathrm{RLP}_{77}$ and $\mathrm{TE}_{77}$ denote relative labor productivity and total employment in 1977, respectively. FULLACQ equals 1 if the firm acquired a 
complete firm; else FULLACQ equals 0. PARTACQ equals 1 if the firm acquired a part of another firm; else PARTACQ equals 0 . BOTH equals 1 if the firm experienced both complete and partial acquisition; otherwise BOTH equals 0 . FOOD equals 1 if the firm primarily produced food products; else FOOD equals 0 . Finally, SUFIRM equals 1 if the firm is a single unit firm; else it equals 0 .

Columns (1) and (2) of Table II present the coefficient estimates based on data for 813 surviving multi-unit firms only. The coefficient for ACQFIRM in Column (1) is statistically insignificant, suggesting that acquisitions did not have a significant effect on a firm's productivity growth. This conclusion holds even when we classify acquiring firms into three categories: complete acquisition, partial acquisition, and both (reported in Column 2). All the coefficients for FULLACQ, PARTACQ, and BOTH are statistically insignificant.

Columns (3) and (4) report the regression results estimated based on data for 5,689 surviving single-unit firms and multiunit non-manufacturing firms. ${ }^{15}$ These results are in sharp contrast to those reported in Columns (1) and (2): the coefficient for ACQFIRM in Column (3) becomes positive and significant at the five percent level, indicating that acquisitions had a significant, positive effect on acquiring firm's productivity growth. When acquiring firms are classified into three categories (Column 4), we find that the coefficients for FULLACQ and BOTH are positive and significant at the five percent level, whereas the coefficient for PARTACQ is insignificant. This evidence provides some support for the

\footnotetext{
Recall that the non-manufacturing firms are those that did not have any manufacturing plants before acquisition. They acquired one or more food manufacturing plants between 1977 and 1982 and kept them through 1987 . Single-unit acquiring firms are those that purchased another single-unit firm or a plant from a multi-unit firm. Thus, the firms included in the estimation of Equations (3) and (4) relied entirely on external growth.
} 
hypothesis that acquisitions of complete firms, rather than purchasing parts of firms through divestitures, are associated with higher subsequent productivity growth.

Finally, Columns (5) and (6) present the results based on the entire data set of 6,499 surviving firms. Again, we find that the coefficient for the ACQFIRM (Column 5) is positive and significant at the one percent level. The coefficients for FULLACQ, PARTACQ, and BOTH are also positive and significant, although the coefficient for PARTACQ is the smallest and the least significant one.

As for other coefficients, we find that the coefficient for the FOOD and SUFIRM variables are statistically insignificant in all equations. While the insignificance of the FOOD coefficient is expected, that of the SUFIRM variable is somewhat surprising. However, because the size of single-unit firms is smaller than that of multi-unit firms, the effect of SUFIRM may be already captured by the size variable $\left(\log \mathrm{TE}_{77}\right)$.

In summary, the results reported in Table II show that acquisitions had a significant, positive effect on the productivity growth of acquiring firms. However, when we include only multi-unit firms in the analysis, we find no significant effect of acquisitions on acquiring firm's productivity growth.

\section{B. Plant-Level Results}

Table III reports the regression results based on plantlevel data. In the table, $\mathrm{ACQ} 7782$ is a dummy variable equal to 1 if the plant is acquired during 1977-82; otherwise it equals 0 . Acquired plants can also be classified into two categories: plants acquired through a complete acquisition (FULLACQ = 1; else FULLACQ $=0$ ), and (2) plants acquired through a partial acquisition (PARTACQ $=1$; else PARTACQ $=0$ ). OWNPLT OFF $_{\text {equals } 1}$ if the plant was originally owned by the acquiring firm in 1977; otherwise OWNPLT $\mathrm{T}_{\mathrm{AF}}=0$. Other variables are defined as before. 
The omitted category is plants owned by non-acquiring firms. Columns (1) and (2) of Table III contain the coefficients estimated using data for 5,386 surviving plants owned by 266 multi-unit acquiring firms and 547 multi-unit non-acquiring firms. The estimates are in sharp contrast with the firm-level results reported in Columns (1) and (2) of Table II. The plantlevel results show that acquisitions had a significant, positive effect on plant's productivity growth: the coefficient for ACQ7782 is significant at the one percent level. When acquired plants are divided into two categories, both the coefficients for FULLACQ and PARTACQ are also significant at the five and ten percent levels.

Columns (3) and (4) of Table III show the regression estimates based on 13,326 surviving plants of 6,502 surviving firms in our data set. Again, the coefficients for ACQ7782, FULLACQ, and PARTACQ are all statistically significant. We also find that the coefficient for FULLACQ is larger and more significant than that for PARTACQ. This means that plants acquired through complete acquisition improved their productivity more than plants acquired through divestitures. However, we find no evidence indicating that plants acquired through divestitures decreased their productivity in the post-acquisition period.

All coefficients for OWNPLT $\mathrm{AF}_{\mathrm{AF}}$ are significant and positive. That is, after controlling for initial conditions and allowing interactions among the key variables, plants initially owned by acquiring firms show higher productivity growth than that observed for non-acquirers' plants. Finally, we find that all the coefficients for the interaction terms (e.g., ACQ7782 * $\log$ $\mathrm{TE}_{77}$ ) are negative and significant. This implies that plants' productivity growth is non-linearly associated with size. For example, using the estimates in Column (4) and using (log) employment at the sample mean (mean $\log \mathrm{TE}_{77}=3.8$ for surviving plants) we find that the productivity of plants acquired through 
complete acquisition during 1977-82 (FULLACQ) grew faster than that of plants owned by non-acquirers by 14.7 percent (i.e., $.394-.065(3.8)=.147)$. However, this advantage of acquired plants diminishes as plant size increases. To be exact, when log $\left(\mathrm{TE}_{77}\right)=6.06$ (i.e., $\left..394 / .065=6.06\right)$ productivity of the acquired plants and that of plants owned by non-acquirers grew at the same rate. Beyond this size (i.e., $\ln \left(\mathrm{TE}_{77}\right)=6.06$ ) productivity of plants owned by non-acquirers grew faster than that of acquired plants. We note, however, that because the 90th percentile value of log $\left(\mathrm{TE}_{77}\right)$ equals 6.00 , only the top five percent of plants owned by non-acquirers had productivity growth that is higher than that of plants acquired through complete acquisitions during 1977-82.

To sum up, our regression results suggest that acquisitions are generally associated with increases in productivity growth. Plant-level results show that both acquired plants and acquiring firms' existing plants increased their productivity 5-9 years after acquisitions. However, for large multi-unit firms, regression results based on firm-level data fail to provide significant gains from acquisitions to acquiring firms. This supports the proposition that regression estimates based on aggregated multi-unit firm data are subject to aggregation biases.

\section{A DECOMPOSITION OF PRODUCTIVITY GROWTH}

\section{A. Method of Decomposition}

To evaluate the contributions of acquisitions on productivity change of a multi-unit firm, we decompose the firm into separate components. In the beginning year of any period over which we desire to measure productivity change, a firm is composed of three types of plants; (i) plants that are kept (k) to the end of the period, (ii) plants that are sold (s) before the end of the period, and (iii) plants that are closed before 
the end of the period. At the end of the period, the firm is also composed of three groups of plants; (i) plants that were originally owned and kept (k), (ii) plants acquired from other firms and kept (a), and (iii) newly built plants (n).

Using these categories the productivity of firm $I, \mathrm{LP}_{i}{ }^{\mathrm{F}}$, in the initial year (b) is written as

$$
L P_{i}^{F}=W_{i k b} L P_{i k b^{+}} W_{i c b} L P_{i c b^{+}} W_{i s b} L P_{i s b^{\prime}}
$$

and the firm's LP in the ending year (e) is

$$
L P_{i}^{F}=w_{i k e} L P_{i k e}+w_{i n e} L P_{i n e}+w_{i a e} L P_{i a e}
$$

where $\mathrm{w}_{i j b}(j=k, c, s)$ and $w_{i j e}(j=k, n, a)$ are the shares of category $j$ in the total employment of firm I in the beginning and ending years, respectively. $L P_{i j b}$ and $L P_{i j e}$ are the weighted average relative labor productivity of category $j$ in firm I in the beginning and ending years. The firm's productivity change is

(4) $\Delta L P_{i}^{F}=L P_{i e}^{F}-L P_{i b}^{F}$.

$$
\begin{aligned}
\Delta L P_{i}^{F} & =\left[w_{i k e}\left(L P_{i k e}-L P_{i k b}\right)+L P_{i k b}\left(w_{i k e}-w_{i k b}\right)\right] \\
& +\left[w_{1 n e}\left(L P_{1 n e}-L P_{1 c b}\right)+L P_{i c b}\left(w_{1 n e}-w_{1 c b}\right)\right] \\
& +\left[w_{i a e}\left(L P_{i a e}-L P_{i s b}\right)+L P_{i s b}\left(w_{i a e}-w_{i s b}\right)\right]
\end{aligned}
$$

Substituting (1) and (2) into (3) and rearranging terms (after some algebraic manipulation) yields

Equation (4) provides a decomposition of the firm's productivity change into three distinct sources: (i) existing plants -- the first bracketed term of the equation, (ii) new plants -- the second bracketed term, and (iii) acquired plants -the third bracketed term. Further, each of the bracketed terms consists of two parts: the first part is a weighted productivity change of the relevant component relative to the firm's initial productivity, and the second part is the contribution of that 
component to the firm's productivity change due to the changes in the component's share of the firm's total employment. We note that, as with the change in productivity of the individual components, the change in their employment shares can be positive or negative. Further, these changes can be in opposite directions. For example, the productivity of a component can increase while its employment share declines. Thus, a component with increasing productivity could make a negative contribution to the firm's productivity growth if its employment share declines enough to offset its productivity growth.

This decomposition provides a framework for assessing the contributions of external and internal changes in the firm's structure to a firm's productivity growth. Moreover, the decomposition is equally valid for firms growing purely through internal means and those using acquisition and divestiture. For convenience, we treat divestitures by non-acquiring firms as closings. This means that firms using strictly internal growth will have zero values for the external growth category.

\section{B. Decomposition Results}

We now turn to the application of this decomposition of productivity change for the multi-unit firms in our sample. Table IV reports the 1977 and 1987 weighted and unweighted average RLPs for both acquiring and non-acquiring firms, changes in their RLPs and the decomposition of these changes over the period 1977-87. Examining first the simple (unweighted) average RLPs, we find that acquiring firms (1977-82) had above-average industry productivity in both 1977 and 1987. Non-acquiring firms' average RLP was just below the industry average in 1977 and 1.5 percent above industry average in 1987. We note, however, that non-acquiring firms show an increase in RLP of 2.2 percentage points, whereas acquiring firms during 1977-82 experienced a 5.6 percentage point decline in RLP. As for firms 
acquiring plants during 1983-87, their 1977 average RLP was 1.02, 2.0 percent above industry average in 1977. By 1987, the average RLP of these firms dropped to .99, a 3.0 percentage point decline in productivity.

When adjusted for size, the employment weighted average RLPs of all surviving multi-unit firms were also well above industry average in both 1977 and 1987. Most noticeably, the average RLPs of acquiring firms during 1977-82 and non-acquiring firms were almost identical in both years. Acquirers showed a 1.5 percentage point increase in RLP change (from 1.108 in 1977 to 1.123 in 1987), whereas non-acquirers experienced a 1.3 percentage point RLP increase during the ten year period. In contrast, firms acquiring plants during 1983-87 showed a 1.7 percentage point decline in RLP during the same period.

These figures, consistent with the earlier regression analysis, show that simply looking at the performance of multiunit firms before and after acquisitions would lead one to conclude that acquisitions bring virtually no gains to acquiring firms. However, the results of the decomposition of productivity change tell a completely different story: acquisitions resulted in substantial gains to acquiring firms. Indeed, Table IV shows that the external component (acquired/sold) is the only component that had positive change in both the productivity and share components. Thus, the external component accounted for virtually all of the productivity gain of acquiring firms. In contrast, both the productivity and share of continuously operating plants declined. Because the productivity measures are relative industry rankings, it is not surprising that the older, continuously operating firms included in Table IV are all survivors already near the top of the ranking in 1977, thus they can do nothing other than fall or stay the same in 1987 . Finally, the internal component (build/closed) shows a positive productivity change. However, this productivity gain is negated 
by the decline of the share of this component in the firm -acquiring firms closed more and bigger plants than they built.

As with acquiring firms, non-acquirers obtained productivity gain from the replacement of closed plants with newly-built plants. However, this gain is offset by a greater decline in the share of this component in the total firm. The major factor that helped non-acquirers maintain or increase their productivity is the expansion of their continuously operating firms, which resulted in a (weighted) average of 22.6 percent increase in productivity due to their employment share increase. We note that during 1977-87, the productivity of non-acquiring firms' continuous plants declined at a weighted average of -.03 while productivity of acquiring firms continuous own plants declined at a weighted average of -.006 . This is consistent with the significant positive coefficient for the variable OWNPLT reported in Table II.

In summary, the results of decomposition of productivity change indicate that acquisitions made a significant contribution to firm productivity growth. Indeed, these results show that while the productivity of the external component (acquired plants) of multi-unit acquiring firms improved substantially after acquisitions, the share of the internal components (continuous existing plants) declined significantly. The two components offset each other and resulted in a small decline in productivity of multi-unit acquiring firms after acquisitions. Thus, assessing the impact of acquisitions on the structure and performance of firms requires a careful look at individual components of the firms, particularly for large multi-unit firms.

\section{DISCUSSION AND CONCLUDING REMARKS}

Our empirical results can be summarized into the following three findings. First, our regression results based on both plant- and firm-level data for the entire population of surviving 
food manufacturing firms over the period 1977-87 show that acquisitions had a significant, positive effect on firms' productivity growth relative to their industries. Second, the regression results based on multi-unit firm-level data show no significant differences in productivity growth between acquiring and non-acquiring firms. Finally, our productivity decomposition results show that while the external component (acquired plants) had a significant, positive contribution to productivity growth of multi-unit acquiring firms, the productivity contribution of their internal component (existing own plants) was negative. Thus, in the restructuring of multi-unit acquiring firms, the two components offset each other, leaving these firms' labor productivity unchanged in the post-acquisition period.

Our first finding is consistent with the results obtained by recent studies using plant-level data. For example, Lichtenberg and Siegel (1992a and 1992b) and McGuckin and Nguyen (1995) used plant-level data taken from the LRD and found that plants having ownership change experienced significant productivity increases. Baldwin and Gorecki (1991) used Canadian plant-level data and found that plants acquired by a firm in the same industry and plants spun off from a continuing company experienced a significant increase in productivity. The above finding is also consistent with most merger theories, including managerialdiscipline and synergy theories. All these theories predict that acquired plants should improve their performance in the postacquisition period.

The second finding implies that productivity performance of multi-unit acquiring firms is generally as good as that of nonacquiring firms. This, in turn, suggests that internal and external growth can be viewed as substitutable methods for firms 
to grow. ${ }^{16}$ As shown in Table IV, the differences in performance that we observe have more to do with the composition of the activities undertaken by the firm, than with the firm's overall performance. Both groups of survivors show small declines in the relative (to the all-industry average) productivity rank of their old plants. This is not surprising since the plants retained over the entire 10-year period have their end-of-the-period efficiency measured against an industry average that excludes low productivity plants that exited after 1977 and includes new entrants with best practice technology. Acquirers also show sharp declines in the share of their activity coming from these kept plants. In contrast, non-acquirers are characterized by increasing concentration in their existing plants. Part of this is algebraic, of course: purchase of new plants will, other things equal, reduce the share of total activity in existing plants. But it is important to note that acquirers increase the productivity of the plants they purchase over pre-merger levels and both acquirers and non-acquirers shut down unproductive plants and build more productive plants. All in all, both groups of surviving firms are undertaking active programs of change.

The third finding shows that while acquisitions make important, positive contributions to the productivity growth of multi-unit acquiring firms, these positive contributions are obscured by the decline in the relative productivity associated with continuous operating plants. The important factor in this decline is the declining share of these continuously operating plants in the firms activities. Because the productivity of these older core plants is much greater than those plants

\footnotetext{
The fact that external and internal growth are substitutes does not imply that all firms are equally able to undertake growth within each method. In this regard, some preliminary work with the multi-unit sample suggests that there is a significant firm-fixed affect associated with a plant's productivity growth.
} 
acquired over the period, the acquisitions tend to reduce the acquiring firm's relative productivity toward the mean productivity. As a result, the productivity of multi-unit acquiring firms remained approximately unchanged for the period 1977-87 when measured on a weighted basis and actually declined on an unweighted basis.

Our concluding comment emphasizes our primary empirical results with respect to aggregation bias and the proper unit of analysis. Using both plant and firm level data for the entire population of surviving food manufacturing firms over the period 1977-87, we find that acquisitions had a significant, positive effect on firms' labor productivity growth relative to their industries. This effect, however, becomes statistically insignificant when we estimate the same model with firm level data for just the larger, multi-unit firms. The source of this difference is the existence of composition effects in the multi-unit firms.

Multi-unit firms are typically the large public companies used in most empirical work on mergers and acquisitions. In light of these results it is not surprising that most previous studies found little in the way of gains to acquiring firms. The composition effects found here for only the manufacturing portions of the firm are likely to be exacerbated when all the diverse operations of acquiring firms are taken into account. In this regard, our empirical results offer one possible explanation for the difference between the results of studies based on firmlevel data and those of plant-level studies on the effect of acquisitions on firms' performance. These results also suggest that assessing the impact of acquisitions on the structure and performance of firms requires a careful look at the individual components (i.e., plants) of the firms, particularly for large multi-unit firms. Therefore, plants rather than firms appear to be the more appropriate unit of analysis. 
While the above conclusions are drawn with a certain degree of confidence, we emphasize that they are strictly applicable to only the food manufacturing industry. In future work, we need to extend the analysis to other industries and go back in time to include previous merger waves. 


\section{REFERENCES}

Abbott, T.A. (1989), "Price Dispersion in U.S. Manufacturing," CES Discussion Paper, CES 89-7, Center for Economic Studies, U.S. Bureau of the Census.

Baily, M.N., Bartelsman, E.J., and Haltiwanger, J. (1994),

"Downsizing and Productivity Growth: Myth or Reality?," CES Discussion Paper, CES 94-4, Center for Economic Studies, U.S. Bureau of the Census.

Baily, M.N., Campbell, D., and Hulten, C. (1992), "The Distribution of Productivity in Manufacturing Plants," Brookings Papers: Microeconomics, 1992.

Baldwin, J. and Gorecki, P. (1991), "Productivity Growth and the Competitive Process: The Role of Firm and Plant Turnover," in P.A. Geroski and J. Schwalbach, Entry and Market

Contestability: An International Comparison, Basil Blackwell, ed., pp. 244-56.

Bartelsman, E.J. and Dhrymes, P.J. (1992), "Productivity Dynamics: U.S. Manufacturing Plants," CES Discussion Paper, CES 92-1, Center for Economic Studies, U.S. Bureau of the Census.

Baumol, W.J. (1967), Business Behavior, Value and Growth, New York: Harcourt, Brace and World.

Berle, A.A. and Means, G. (1932), The Modern Corporation, New York: MacMillan.

Christensen, L.R., Cummings, D., and Jorgenson, D.W. (1981), "Relative Productivity Levels 1947-1973: An International Comparison," European Economic Review, 16, pp. 61-94.

Grossman, S.J. and Hart, O.D. (1979), "Takeover Bids, the FreeRider Problem, and the Theory of the Corporation," Bell Journal of Economics, 8, pp. 42-64.

Jarrell, G.A., Brickley, J.A., and Netter, J.M. (1988), "The Market for Corporate Control: The Empirical Evidence Since 1980," Journal of Economic Perspectives, 2, pp. 49-68.

Jensen, M.C. (1988), "The Takeover Controversy: Analysis and Evidence," in Knights, Raiders, and Targets: The Impact of Hostile Takeover, J.C. Coffee, Jr., L. Lowenstein, and S. Rose-Ackerman (eds.), Oxford: Oxford University Press. 
Jensen, M.C. and Ruback, R.S. (1983), "The Market for Corporate Control: The Scientific Evidence," Journal of Financial Economics, 11, pp. 5-50.

Kaplan, S. (1989), "The Effect of Management Buyouts on Operating Performance and Value," Journal of Financial Economics, 24, pp. 217-54.

Klein, P.G. (1994), "Did the Conglomerates Add Values?," working paper, Department of Economics, University of California, Berkeley.

Lichtenberg, F.R. (1992), Corporate Takeovers and Productivity, Cambridge: The MIT Press.

Lichtenberg, F.R. and Siegel, D. (1992a), "Productivity and Changes in Ownership of Manufacturing Plants," in Corporate Takeovers and Productivity, F.R. Lichtenberg, ed., Cambridge: The MIT Press, pp. 25-43.

Lichtenberg, F.R. and Siegel, D. (1992b), "Leveraged Buyouts," in Corporate Takeovers and Productivity, F.R. Lichtenberg, ed., Cambridge: The MIT Press.

Long, W.F., and Ravenscraft, D.J. (1993) "The Financial Performance of Whole Company LBOs," CES Discussion Paper, CES 93-16, Center for Economic Studies, U.S. Bureau of the Census.

Manne, H.G. (1965), "Mergers and the Market for Corporate Control," Journal of Political Economy, 73, pp. 110-20.

Matsusaka, J.G. (1993a), "Takeover Motives During the Conglomerate Merger Wave," RAND Journal of Economics, 24, 3.

McGuckin, R.H. and Pascoe, G. (1988), "The Longitudinal Research Database: Status and Research Possibilities," Survey of Current Business, 68, 11, pp. 30-37.

McGuckin, R.H. and Nguyen, S.V. (1995), "On Productivity and Plant Ownership Change: New Evidence from the LRD," The RAND Journal of Economics, 26, 2, pp. 257-76.

McGuckin, R.H., Nguyen, S.V., and Reznek, A.P. (1995), "The Impact of Ownership Change on Employment, Wages, and Labor Productivity in U.S. Manufacturing 1977-87," CES Discussion Paper, CES 95-8, Center for Economic Studies, U.S. Bureau of the Census. 
McGuckin, R.H., Warren-Boulton, F., and Waldstein, P. (1992), "The Use of Stock Market Returns in Antitrust Analysis of Mergers," Review of Industrial Organization, 7, pp. 1-11.

Meade, J.E. (1968), "Is the New Industrial State Inevitable?," Economic Journal, 78, pp. 372-92.

Mueller, D.C. (1969), "A Theory of Conglomerate Mergers," Quarterly Journal of Economics, 83, pp. 643-59.

Mueller, D.C. (1985), "Mergers and Market Share," The Review of Economics and Statistics, 24, pp. 259-67.

Mueller, D.C. (1993), "Mergers: Theory and Evidence," mimeo.

Olley, G.S. and Pakes, A. (1992), "The Dynamics of Productivity in the Telecommunication Equipment Industry," Working Paper Number 3977, National Bureau of Economic Research.

Ravenscraft, D.J. and Scherer, F.M. (1987), Mergers, Sell-0ffs, and Economic Efficiency, Washington, D.C.: The Brookings Institution.

Roll, R. (1986), "The Hubris Hypothesis of Corporate Takeovers," Journal of Business, 59, pp. 197-216.

Shleifer, A. and Vishny, R.W. (1989), "Management Entrenchment: The Case of Manager-Specific Investment," Journal of

Financial Economics, 25, pp. 123-39.

Smith, A. (1990), "Corporate Ownership Structure and Performance: The Case of Management Buyouts," Journal of Financial

Economics, 27, pp. 143-64.

Smith, C.W., Jr. (1986), "Investing Banking and the Capital Acquisition Process," Journal of Financial Economics, 15, pp. 3-29.

Stigler, G.J. (1950), "Monopoly and Oligopoly by Merger," American Economic Review, 40, pp. 23-34. 
TABLE I

ACQUIRING AND NON-ACQUIRING FOOD PRODUCING FIRMS, 1977

\begin{tabular}{|c|c|c|c|c|c|c|c|}
\hline & \multicolumn{3}{|c|}{ Number of Firms } & \multirow{2}{*}{$\begin{array}{c}\text { Total } \\
\text { Shipments } \\
(000,000)\end{array}$} & \multirow{2}{*}{$\begin{array}{c}\text { Total } \\
\text { Employment }\end{array}$} & \multirow{2}{*}{$\begin{array}{c}\text { Average } \\
\text { Employment }\end{array}$} & \multirow{2}{*}{$\begin{array}{c}\text { Relative Labor } \\
\text { Productivity } \\
1977\end{array}$} \\
\hline & Food $^{a}$ & Non-Food & Total & & & & \\
\hline \multicolumn{8}{|l|}{$\underline{\text { ACQUIRING FIRMS }}$ (1977-82) } \\
\hline 1. Single-Unit Firms & 62 & 31 & 93 & 1,381 & 14,694 & 158 & .96 \\
\hline $\begin{array}{l}\text { 2. Non-Manufacturing (bought } \\
1 \text { food plant) }\end{array}$ & 109 & 25 & 134 & 1,798 & 17,554 & 131 & .96 \\
\hline $\begin{array}{l}\text { 3. Non-Manufacturing (bought } \\
\text { more than } 1 \text { food plant) }\end{array}$ & 103 & 47 & 150 & 9,623 & 75,600 & 504 & 1.04 \\
\hline $\begin{array}{l}\text { 4. Multi-Unit Manufacturing } \\
\text { Firms }\end{array}$ & 236 & 119 & 355 & 172,164 & $1,203,095$ & 3,389 & 1.11 \\
\hline TOTAL & 510 & 222 & 732 & 184,967 & $1,278,695$ & 1,747 & 1.05 \\
\hline \multicolumn{8}{|l|}{$\begin{array}{l}\text { NON-ACQUIRING FIRMS* } \\
(1977-82)\end{array}$} \\
\hline 1. Single-Unit & 15,067 & ---- & 15,067 & 26,124 & 286,273 & 19 & .78 \\
\hline $\begin{array}{l}\text { 2. Non-Manufacturing (with } \\
1 \text { food plant) }\end{array}$ & 1,185 & ----- & 1,185 & 8,361 & 82,950 & 70 & .87 \\
\hline 3,4. Multi-Unit Firms ${ }^{\mathrm{c}}$ & 1,001 & 156 & 1,157 & 129,466 & $1,253,031$ & 1,083 & 1.00 \\
\hline TOTAL & 17,253 & 156 & 17,409 & 163,931 & $1,622,254$ & 93 & .80 \\
\hline
\end{tabular}

Firms are allocated to food or non-food industries based on the largest category of shipments.

These firms had no acquisitions in the 1977-82 period, but may have had acquisitions in the 1983-87 period.

Includes multi-unit firms with non-manufacturing operations. 
TABLE II

REGRESSION OF SURVIVING FIRMS' PRODUCTIVITY GROWTH

(t-ratios in parentheses)

Dependent Variable: $\log \left(\mathbf{R L P}_{87} / \mathbf{R L P}_{77}\right)$

\begin{tabular}{|c|c|c|c|c|c|c|}
\hline \multirow[b]{2}{*}{ Independent Variable } & \multicolumn{2}{|c|}{$\begin{array}{c}\text { Multi-Unit } \\
\text { Manufacturing Firms } \\
\end{array}$} & \multicolumn{2}{|c|}{$\begin{array}{c}\text { Single-Unit and } \\
\text { Non-Manufacturing Firms } \\
\end{array}$} & \multicolumn{2}{|c|}{ All Firms } \\
\hline & (1) & (2) & (3) & (4) & (5) & (6) \\
\hline Intercept & $\begin{array}{c}.412^{* *} \\
(3.3)\end{array}$ & $\begin{array}{c}.434 * * \\
(3.4)\end{array}$ & $\begin{array}{c}.428 * * \\
(3.1)\end{array}$ & $\begin{array}{c}.443 * * \\
(3.1)\end{array}$ & $\begin{array}{c}.319 * * \\
(4.7)\end{array}$ & $\begin{array}{c}.330 * * \\
(4.7)\end{array}$ \\
\hline $\mathrm{RLP}_{77}$ & $\begin{array}{c}-.258 * * \\
(4.8)\end{array}$ & $\begin{array}{c}-.260 * * \\
(4.8)\end{array}$ & $\begin{array}{c}-1.023 * * \\
(26.1)\end{array}$ & $\begin{array}{c}-1.024 * * \\
(26.1)\end{array}$ & $\begin{array}{c}-.820 * * \\
(28.7)\end{array}$ & $\begin{array}{c}-.821 * * \\
(2.4)\end{array}$ \\
\hline $\log \left(\mathrm{TE}_{77}\right)$ & $\begin{array}{r}-.018 \\
(0.9)\end{array}$ & $\begin{array}{r}-.019 \\
(0.9)\end{array}$ & $\begin{array}{r}-.008 \\
(0.7)\end{array}$ & $\begin{array}{r}-.009 \\
(0.7)\end{array}$ & $\begin{array}{c}.023 * * \\
(2.5)\end{array}$ & $\begin{array}{c}.022 * * \\
(2.4)\end{array}$ \\
\hline ACQFIRM (1977-82) & $\begin{array}{r}-.242 \\
(1.5)\end{array}$ & ----- & $\begin{array}{l}.414^{*} \\
(2.0)\end{array}$ & ----- & $\begin{array}{c}.488 * * \\
(4.1)\end{array}$ & ----- \\
\hline FULLACQ & ----- & $\begin{array}{r}-.280 \\
(1.3)\end{array}$ & ----- & $\begin{array}{l}.585^{*} \\
(1.7)\end{array}$ & ----- & $\begin{array}{c}.470 * * \\
(2.7)\end{array}$ \\
\hline PARTACQ & ----- & $\begin{array}{r}-.271 \\
(1.2)\end{array}$ & ----- & $\begin{array}{r}-.019 \\
(0.5)\end{array}$ & ----- & $\begin{array}{l}.336^{*} \\
(1.9)\end{array}$ \\
\hline ВOTH & ----- & $\begin{array}{l}.044 \\
(0.1)\end{array}$ & ----- & $\begin{array}{c}1.929 * \\
(2.2)\end{array}$ & ----- & $\begin{array}{c}1.104 * * \\
(3.1)\end{array}$ \\
\hline $\log \left(\mathrm{TE}_{77}\right) *$ ACQFIRM & $\begin{array}{l}.050^{*} \\
(2.0)\end{array}$ & ----- & $\begin{array}{c}-.085 * \\
(2.1)\end{array}$ & ----- & $\begin{array}{c}-.092 * * \\
(4.8)\end{array}$ & ----- \\
\hline $\log \left(\mathrm{TE}_{77}\right) *$ FULLACQ & ----- & $\begin{array}{c}.059+ \\
(1.7)\end{array}$ & ----- & $\begin{array}{l}-.111 \\
(1.5)\end{array}$ & ----- & $\begin{array}{c}-.084 * * \\
(2.9)\end{array}$ \\
\hline $\log \left(\mathrm{TE}_{77}\right) *$ PARTACQ & ----- & $\begin{array}{l}.045 \\
(1.3)\end{array}$ & ----- & $\begin{array}{r}-.008 \\
(0.1)\end{array}$ & ----- & $\begin{array}{c}-.080 * * \\
(2.6)\end{array}$ \\
\hline $\log \left(\mathrm{TE}_{77}\right) * \mathrm{BOTH}$ & ----- & $\begin{array}{l}.018 \\
(0.4)\end{array}$ & ----- & $\begin{array}{l}-.327 * * \\
\quad(2.4)\end{array}$ & ----- & $\begin{array}{c}-.173 * * \\
(3.6)\end{array}$ \\
\hline $\log \left(\mathrm{TE}_{77}\right) * \mathrm{RLP}_{77}$ & $\begin{array}{r}-.003 \\
(0.4)\end{array}$ & $\begin{array}{r}-.003 \\
(0.4)\end{array}$ & $\begin{array}{l}.133 * * \\
(10.7)\end{array}$ & $\begin{array}{l}.134 * * \\
(10.8)\end{array}$ & $\begin{array}{c}.079 * * \\
(11.2)\end{array}$ & $\begin{array}{l}.079 * * \\
(11.1)\end{array}$ \\
\hline FOOD & $\begin{array}{r}-.041 \\
(0.8)\end{array}$ & $\begin{array}{l}-.060 \\
(1.1)\end{array}$ & $\begin{array}{l}.027 \\
(0.2)\end{array}$ & $\begin{array}{l}.010 \\
(0.1)\end{array}$ & $\begin{array}{l}.016 \\
(0.3)\end{array}$ & $\begin{array}{l}.004 \\
(0.1)\end{array}$ \\
\hline SUFIRM & ----- & ----- & $\begin{array}{l}.013 \\
(0.1)\end{array}$ & $\begin{array}{l}-.001 \\
(0.01)\end{array}$ & $\begin{array}{r}-.009 \\
(0.2)\end{array}$ & $\begin{array}{r}-.019 \\
(0.3)\end{array}$ \\
\hline $\mathrm{R}^{2}$ & .1617 & .1598 & .2459 & .2461 & .2220 & .2220 \\
\hline $\mathrm{n}$ & 813 & 813 & 5,689 & 5,689 & 6,502 & 6,502 \\
\hline
\end{tabular}

* denotes "significant" at the five percent level.

** denotes "significant" at the one percent level. 
TABLE III

REGRESSION OF SURVIVING PLANTS' PRODUCTIVITY GROWTH

(t-ratios in parentheses)

Dependent Variable: $\log \left(\operatorname{RLP}_{87} / \mathbf{R L P}_{77}\right)$

\begin{tabular}{|c|c|c|c|c|}
\hline \multirow[b]{2}{*}{ Independent Variable } & \multicolumn{2}{|c|}{$\begin{array}{l}\text { Plants of Multi-Unit } \\
\text { Manufacturing Firms }\end{array}$} & \multicolumn{2}{|c|}{ Plants of All Firms } \\
\hline & (1) & (2) & (3) & (4) \\
\hline Intercept & $\begin{array}{l}.126^{*} \\
(2.1)\end{array}$ & $\begin{array}{l}.128 * \\
(2.2)\end{array}$ & $\begin{array}{c}-.093 * * \\
(3.6)\end{array}$ & $\begin{array}{c}-.088 * * \\
(3.4)\end{array}$ \\
\hline $\mathrm{RLP}_{77}$ & $\begin{array}{c}-.259 * * \\
(8.5)\end{array}$ & $\begin{array}{c}-.259 * * \\
(8.5)\end{array}$ & $\begin{array}{l}-.148 * * \\
(11.9)\end{array}$ & $\begin{array}{c}-.148 * * \\
(11.9)\end{array}$ \\
\hline $\log \left(\mathrm{TE}_{77}\right)$ & $\begin{array}{c}.061 * * \\
(5.0)\end{array}$ & $\begin{array}{c}.061 * * \\
(5.0)\end{array}$ & $\begin{array}{l}.085^{* *} \\
(14.2)\end{array}$ & $\begin{array}{l}.085 * * \\
(14.2)\end{array}$ \\
\hline ACQ7782 & $\begin{array}{l}.252 * * \\
(2.8)\end{array}$ & ---- & $\begin{array}{l}.339 * * \\
(4.1)\end{array}$ & ----- \\
\hline FULLACQ & ----- & $\begin{array}{l}.261^{*} \\
(2.2)\end{array}$ & ----- & $\begin{array}{c}.394 * * \\
(3.4)\end{array}$ \\
\hline PARTACQ & ----- & $\begin{array}{l}.196+ \\
(1.6)\end{array}$ & ----- & $\begin{array}{l}.233^{*} \\
(2.0)\end{array}$ \\
\hline $\mathrm{OWNPLT}_{\mathrm{AF}}$ & $\begin{array}{l}.408 * \\
(6.4)\end{array}$ & $\begin{array}{c}.407 * * \\
(6.4)\end{array}$ & $\begin{array}{c}.471 * * \\
(7.8)\end{array}$ & $\begin{array}{c}.472 * * \\
(7.8)\end{array}$ \\
\hline ACQ7782 * $\log \left(\mathrm{TE}_{77}\right)$ & $\begin{array}{c}-.045 * * \\
(2.4)\end{array}$ & ----- & $\begin{array}{c}-.006 * * \\
(3.9)\end{array}$ & ----- \\
\hline FULLACQ $* \log \left(\mathrm{TE}_{77}\right)$ & ----- & $\begin{array}{c}-.038+ \\
(1.6)\end{array}$ & ----- & $\begin{array}{c}-.065 * * \\
(2.7)\end{array}$ \\
\hline PARTACQ $* \log \left(\mathrm{TE}_{77}\right)$ & ---- & $\begin{array}{c}-.042+ \\
(1.6)\end{array}$ & ----- & $\begin{array}{c}-.055^{* *} * \\
(2.4)\end{array}$ \\
\hline $\mathrm{OWNPLT}_{\mathrm{AF}} * \log \left(\mathrm{TE}_{77}\right)$ & $\begin{array}{c}-.076 * * \\
(5.8)\end{array}$ & $\begin{array}{c}-.076 * * \\
(5.8)\end{array}$ & $\begin{array}{c}-.091 * * \\
(7.5)\end{array}$ & $\begin{array}{c}-.091 * * \\
(7.5)\end{array}$ \\
\hline $\mathrm{RLP}_{77} * \log \left(\mathrm{TE}_{77}\right)$ & $\begin{array}{c}-.018 * * \\
(2.7)\end{array}$ & $\begin{array}{l}-.018 * * \\
\quad(2.7)\end{array}$ & $\begin{array}{l}-.021 * * \\
\quad(6.5)\end{array}$ & $\begin{array}{c}-.021 * * \\
(6.5)\end{array}$ \\
\hline FOOD & $\begin{array}{c}-.079 * * \\
(4.9)\end{array}$ & $\begin{array}{c}-.083 * * \\
(5.1)\end{array}$ & $\begin{array}{c}-.081 * * \\
(5.4)\end{array}$ & $\begin{array}{c}-.086^{* *} \\
(5.7)\end{array}$ \\
\hline SUFIRM & ----- & ----- & .001 & -.002 \\
\hline $\mathrm{R}^{2}$ & .2336 & .2339 & .1733 & .1736 \\
\hline $\mathrm{n}$ & 5,386 & 5,386 & 13,326 & 13,326 \\
\hline
\end{tabular}

$+\quad$ denotes "significant" at the ten percent level.

* denotes "significant" at the five percent level.

** denotes "significant" at the 1 percent level. 
TABLE IV

EVOLUTION OF THE FIRM: THE COMPONENTS OF PRODUCTIVITY GROWTH, $1977-87^{\mathrm{a}} \mathrm{b}$

Components of Growth

\begin{tabular}{|c|c|c|c|c|c|c|c|c|c|c|}
\hline \multirow[b]{2}{*}{ Observation Year/Period } & \multirow[b]{2}{*}{$\mathbf{n}$} & \multicolumn{2}{|c|}{$\begin{array}{c}\text { Internal } \\
\text { (Continuously } \\
\text { Operating) } \\
\end{array}$} & \multicolumn{2}{|c|}{$\begin{array}{c}\text { External } \\
\text { (Acquired/Sold) }\end{array}$} & \multicolumn{2}{|c|}{$\begin{array}{c}\text { Internal } \\
\text { (Built/Closed) }\end{array}$} & \multirow[b]{2}{*}{$\begin{array}{c}\text { Productivity } \\
\text { Change }\end{array}$} & \multicolumn{2}{|c|}{ Total Firm } \\
\hline & & $\begin{array}{c}\text { Productivity } \\
\text { Change }\end{array}$ & $\begin{array}{c}\text { Share } \\
\text { Change }\end{array}$ & $\begin{array}{c}\text { Productivity } \\
\text { Change }\end{array}$ & $\begin{array}{c}\text { Share } \\
\text { Change }\end{array}$ & $\begin{array}{c}\text { Productivity } \\
\text { Change }\end{array}$ & $\begin{array}{c}\text { Share } \\
\text { Change }\end{array}$ & & $\begin{array}{l}1977 \\
\text { RLP } \\
\end{array}$ & $\begin{array}{l}1987 \\
\text { RLP } \\
\end{array}$ \\
\hline \multicolumn{11}{|c|}{ Acquirers } \\
\hline 1977-82 (weighted) & 266 & -.006 & -.190 & .141 & .171 & .019 & -.120 & .015 & 1.108 & 1.123 \\
\hline 1977-82 (unweighted) & 266 & -.026 & -.222 & .251 & .047 & .049 & -.155 & -.056 & 1.136 & 1.080 \\
\hline 1983-87 (weighted) & 117 & -.011 & -.064 & .072 & .018 & .019 & -.050 & -.017 & 1.049 & 1.032 \\
\hline 1983-87 (unweighted) & 117 & -.042 & -.178 & .205 & .013 & .048 & -.076 & -.030 & 1.020 & .990 \\
\hline 1977-87 (weighted) & 383 & -.006 & -.137 & .116 & .115 & .019 & -.098 & .010 & 1.087 & 1.097 \\
\hline 1977-87 (unweighted) & 383 & -.031 & -.208 & .237 & .037 & .048 & -.133 & -.049 & 1.103 & 1.054 \\
\hline \multicolumn{11}{|c|}{ Non-Acquirers } \\
\hline (Weighted) & 547 & -.030 & .226 & ---- & ---- & .077 & -.260 & .013 & 1.113 & 1.126 \\
\hline (Unweighted) & 547 & -.016 & .049 & ----- & ----- & .090 & -.101 & .022 & .993 & 1.015 \\
\hline
\end{tabular}

Weighted productivity is calculated using total firm employment weights. 
CENTER FOR ECONOMIC STUDIES DISCUSSION PAPERS

95-13 "Exploring the Role of Acquisition in the Performance of Firms: Is the "Firm" the Right Unit of Analysis?", by Robert H. McGuckin and Sang V. Nguyen, 11/95. (29 pages, \$7.25).

95-12 "The Missing Link: Technology, Productivity, and Investment", by Laura Power, 10/95. (39 pages, \$9.75).

95-11 "Counting the Self-Employed From Two Perspectives: Household vs. Business Sample Data", by Richard J. Boden and Alfred R. Nucci, 8/95. (22 pages, \$5.50).

95-10 "The Worker-Establishment Characteristics Database", by Kenneth R. Troske, 6/95. (45 pages, \$11.25).

95-9 "Retail Inventories, Internal Finance, and Aggregate Fluctuations: Evidence from Firm-Level Panel Data", by Egon Zakrajsek, 5/95. (40 pages, $\$ 10.00)$.

95-8 "The Impact of Ownership Change on Employment, Wages, and Labor Productivity in U.S. Manufacturing 1977-87", by Robert H. McGuckin, Sang V. Nguyen, and Arnold P. Reznek, 4/95. (57 pages, \$14.25).

95-7 "Using Matched Client and Census Data to Evaluate the Performance of the Manufacturing Extension Partnership", by Ron S. Jarmin, 4/95. (40 pages, $\$ 10.00)$.

95-6 "Technology Locks, Creative Destruction and Non-Convergence in Productivity Levels", By Douglas Dwyer, 4/95. (59 pages, \$14.75).

95-5 "Whittling Away at Productivity Dispersion", by Douglas Dwyer, $3 / 95$. (37 pages,

$\$ 9.25)$.

95-4 "Capital Structure and Product Market Behavior: An Examination of Plant Exit and Investment Decisions", by Dan Kovenock and Gordon M. Phillips, 3/95. (56 pages, \$14.00).

95-3 "Capital Structure and Product Marker Rivalry: How Do We Reconcile Theory and Evidence?", by Dan Kovenock and Gordon Phillips, $2 / 95$. (15 pages, \$3.75).

95-2 "Small Businesses Do Appear to Benefit from State/Local Government Economic Development Assistance", by Timothy Bates, 2/95.

(35 pages, \$8.75).

95-1 "Preferential Procurement Programs do not Necessarily Help MinorityOwned Businesses", by Timothy Bates and Darrell Williams, 1/95.

(36

pages, $\$ 9.00)$

94-14 "Pollution Abatement Costs, Regulation and Plant-Level

Productivity", by Wayne B. Gray and Ronald J. Shadbegian, 12/94. (27 pages, \$6.75).

94-13 "Exporters, Skill Upgrading and the Wage Gap," by Andrew B. Bernard and J. Bradford Jensen, 11/94. (40 pages, \$10.00).

94-12 "Primary Versus Secondary Production Techniques in U.S. Manufacturing," by Joe Mattey, 10/94. (24 pages, \$6.00). 
94-11 "Capital Adjustment Patterns in Manufacturing Plants," by Mark Doms and Timothy Dunne, 8/94. (40 pages, \$10.00).

94-10 "Evidence on the Employer Size-Wage Premium From WorkerEstablishment Matched Data," by Kenneth R. Troske, 8/94. (52 pages, $\$ 13.00)$.

94-9 "A Guide to $\mathrm{R} \& \mathrm{D}$ Data at the Center for Economic Studies U.S. Bureau of the Census," by James D. Adams and SuZanne Peck, 8/94. (64 pages, $\$ 16.00)$.

94-8 "Cross Sectional Variation in Toxic Waste Releases from the U.S. Chemical Industry," by Mary L. Streitwieser, 8/94. (44 pages, $\$ 11.00$ ).

94-7 "The Span of the Effect of $R \& D$ in the Firm and Industry," by James D. Adams and Adam B. Jaffe, 6/94. (37 pages, \$9.25).

94-6 "Regulation and Firm Size, Foreign-Based Company Market Presence, Merger Choice in the U.S. Pesticide Industry," by Michael Ollinger and Jorge Fernandez-Cornejo, 6/94. (33 pages, \$8.25).

94-5 "Recent Twists of the Wage Structure and Technology Diffusion" by James D. Adams, 6/94. (61 pages, \$15.25)

94-4 "Downsizing and Productivity Growth: Myth or Reality?" by Martin Neil Baily, Eric J. Bartelsman and John Haltiwanger, 5/94. (34 pages, \$8.50)

94-3 "Firms Started as Franchises Have Lower Survival Rates than Independent Small Business Startups," by Timothy Bates 5/94. (27 pages, \$6.75)

94-2 "A Comparison of Job Creation and Job Destruction in Canada and the United States," by John Baldwin, Timothy Dunne, and John Haltiwanger, 5/94. (32 pages, \$8.00)

94-1 "The Choice of Input-Output Table Embedded in Regional Econometric Input-Output Models," by Philip R. Israilevich, R. Mahidara, and Geoffrey J.D. Hewings, 1/94. (22 pages, \$5.50)

CES Discussion Paper listings dated back to 1988 are available upon request.

CES Discussion Papers are available in a variety of subscription formats: (INTERNET, WordPerfect 5.1 Diskette, and Yearly Series single paper copy). Ordering information is found on the attached CES Discussion Paper Subscription \& Request Form. In addition, papers are sold individually for the amount specified after each title. 


\section{CES Discussion Paper Subscription and Request Form}

Yes, I'd like to subscribe to the following:

Regular announcements of the CES Discussion Paper Series on the INTERNET, free of charge.

$\square \quad$ Yearly subscription to the CES Discussion Paper Series in single paper copy for a fee of $\$ 125.00$ per year.

$\square \quad$ Yearly subscription to the CES Discussion Paper Series on computer diskette in WordPerfect 5.1 for a fee of

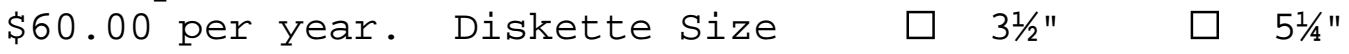

The CES Annual Report is available (free of charge). Please add my name to your mailing list.

No, I don't want to subscribe at this time but, I would like to order the following CES Discussion Paper(s): CES\# CES\# CES\# Total \$

NAME

ADDRESS

Phone ( )

$\operatorname{FAX} \quad($

INTERNET ADDRESS

$\square$ Check here if this is an change of address.

METHOD OF PAYMENT (Payable to: Commerce, Census

$\square$ Check $\square$ Money order $\square$ Mastercard $\square$ Visa

Card Number

Expiration Date:

Month

Year

Amount enclosed: \$

Please send order form and payment to:

Bureau of the Census

Economic Planning and Coordination

Center for Economic Studies 
Room 1587-3

Washington D.C. 20233-6101

Attn: Tracy C. Crosby 